ТЕОРЕТИЧНІ ПРОБЛЕМИ РОЗВИТКУ НАЦІОНАЛЬНОЇ ЕКОНОМІКИ

УДК $330.341: 379.8$

DOI: $10.25140 / 2411-5215-2020-1(21)-9-19$

Валерій Ільчук, Ірина Садчикова

\title{
ТЕОРЕТИЧНІ ЗАСАДИ ФОРМУВАННЯ КРЕАТИВНИХ ІНДУСТРІЙ У РОЗВИТКУ РЕАЛЬНОГО СЕКТОРУ НАЦІОНАЛЬНОЇ ЕКОНОМІКИ
}

\author{
Валерий Ильчук, Ирина Садчикова \\ ТЕОРЕТИЧЕСКИЙ ОСНОВЫ ФОРМИРОВАНИЯ КРЕАТИВНЫХ \\ ИНДУСТРИЙ В РАЗВИТИИ РЕАЛЬНОГО СЕКТОРА \\ НАЦИОНАЛЬНОЙ ЭКОНОМИКИ
}

Valerii Ilchuk, Iryna Sadchykova

\section{THEORETICAL FUNDAMENTALS OF CREATIVE INDUSTRY FORMATION IN THE DEVELOPMENT OF THE REAL SECTOR OF THE NATIONAL ECONOMY}

У статті трунтовно досліджено сутність креативних індустрій від зародження до їх становлення та розвитку. Також було визначено, що креативні індустрії в реальному секторі економіки виявляються в інноваціях $і$ спрямовані в багатьох випадках на створення нових ідей та інтелектуальної власності в науково-інновачійній, технікотехнологічній, організачійно-економічній сферах, які забезпечують матеріальну основу життєдіяльності суспільства та кожної людини окремо. Наведено схему використання креативних індустрій у реальному секторі національної економіки. Виділено види креативних індустрій за напрямами створення духовних та матеріальних благ, а також показано вплив креативних індустрій на розвиток реального сектору національної економіки.

Ключові слова: креативність; творчість; креативна економіка; реальний сектор; креативні індустрії; інноваційність; творчий підхід.

Рис.: 6. Бібл.: 10.

В статье основательно исследована сущность креативных индустрий от зарождения до их становления и развития. Также было определено, что креативные индустрии в реальном секторе экономики оказываются в инновачиях и направлены во многих случаях на создание новых идей и интеллектуальной собственности в научноинновационной, технико-технологической, организачионно-экономической сферах, обеспечиваюших материальную основу жизнедеятельности общества и каждого человека в отдельности. Приведена схема использования креативных индустрий в реальном секторе начиональной экономики. Выделены виды креативных индустрий по направлениям создания духовных и материальных благ, а также показано влияние креативных индустрий на развитие реального сектора начиональной экономики.

Ключевые слова: креативность; творчество; креативная экономика; реальный сектор; креативная индустрия; инновачионность; творческий подход.

Рис.: 6. Библ.: 10.

The article thoroughly investigates the essence of creative industries from their inception to their formation and development. It was also determined that the creative industries in the real sector of the economy are emerging in innovation and in many cases aimed at creating new ideas and intellectual property in scientific-innovation, technical, technological, organizational and economic spheres, which provide the material basis for the life of society and every human being. The scheme of use of creative industries in the real sector of national economy is presented. The types of creative industries in the directions of creation of spiritual and material goods are highlighted, as well as the influence of creative industries on the development of the real sector of the national economy.

Key words: creativity; creative economy; real sector; creative industry; innovativeness; creative approach.

Fig.: 6. Bibl.: 10 .

JEL Classification: Z10; O16; H00

Постановка проблеми. Новим етапом функціонування та розвитку світової економічної системи став перехід від традиційної економіки до економіки, основою якої $\epsilon$ знання, інтелектуальна праця, інновації, досягнення науки й техніки, поширення інформаційних технологій у різні сфери господарювання, тобто творча або креативна економіка. Творча (креативна) складова на сьогодні стає основною вимогою для конкурентоспроможності будь-якого підприємства реального сектору національної економіки. Креативний підхід дозволяє віднайти нові, унікальні рішення в динамічному зовнішньому середовищі. Процеси глобалізації ставлять нові вимоги та масштаби для ведення бізнесу, а також створюють умови для поєднання економіки знань та креативності.

(C) Ільчук В. П., Садчикова I. В., 2020 
ТЕОРЕТИЧНІ ПРОБЛЕМИ РОЗВИТКУ НАЦІОНАЛЬНОЇ ЕКОНОМІКИ

Аналіз останніх досліджень та публікацій. Дослідження питань, пов'язаних із креативною економікою, на фундаментальному рівні проводили такі закордонні вчені, як П. Бурдье, Е. Бустаманте, Р. Діаз-Боуном, П. Кавес, Г. Крелла, П. Шлесингером, Дж. Хокінс, Ч. Лендрі, Р. Флоріда, Т. Флемінг, Дж. Поттс, П. Маркузе, М. Меттьюс, П. Холл, Дж. О’Конор, Р. Кейвз, Й. Клоудова, Є. Мельвіль, Є. Зеленцова, Л. Востряков та ін.

У вітчизняних дослідженнях знайшли відображення окремі питання, пов'язані з розвитком креативної економіки, функціонуванням креативних індустрій, у працях таких науковців, як Л. Антошкіна, І. Брикова, П. Бубенко, Б. Буркинський, З. Герасимчук, П. Гудзь, О. Дацко, Н. Мікула, В. Орловська, Ю. Орловська, Л. Федулова, Н. Рудь, В. Чала, В. Чужиков та багато інших.

Виділення недосліджених частин загальної проблеми. Проте незважаючи на численні праці з окресленням питань сутності та особливостей розвитку креативної економіки та креативних індустрій, малодослідженими залишаються теоретико-методичні та прикладні аспекти формування креативних індустрій у розвитку реального сектору національної економіки.

Мета статті. Метою цього дослідження $є$ визначення сутності та умов формування креативних індустрій, їх використання в реальному секторі економіки та впливу креативних індустрій на розвиток креативної економіки.

Виклад основного матеріалу. Креативні індустрії та формування на їх базі креативної економіки набувають сьогодні дедалі більшого поширення і стають основою інноваційного підприємництва та інноваційних зрушень у всіх сферах суспільної діяльності й у всіх секторах національної економіки.

Креативні індустрії набули найбільшого розвитку в Англії, де ще в 1998 році Департаментом медіа, культури і спорту було сформульовано поняття «креативні індустрії», під якими розуміли індивідуальну творчість, уміння і талант, які мають потенціал у створенні доданої вартості й робочих місць через створення та використання інтелектуальної власності [8].

Креативні індустрії виявляються в генеруванні ідей і нових знань та їхньому розвитку $з$ орієнтацією на створення нових продуктів, які мають споживчу цінність, що особливо важливо для комерціалізації креативних ініціатив.

Перші визначення креативних індустрій стосувались таких галузей, як мистецтво, ремесла, дизайн, мода, кіно, музика тощо, де центральну роль відіграє творча особистість. Пізніше стало більш популярне твердження, що креативна індустрія - це індустрія інновацій у науці, технологіях, культурі, духовному житті й т. ін. На сьогодні термін «креативні індустрії» не зводяться до вузького розуміння як «індустрія культури» і має більш широке значення.

Для України на сьогодні формування креативних індустрій має спрямовуватись не стільки в бік розваг, культури, мистецтва та ін., скільки на створення нових високих технологій. Розвиток креативних індустрій, а сама IT-сектору та інших високотехнологічних галузей економіки з високою доданою вартість $\epsilon$ стратегічним напрямом розвитку національної економіки.

На сьогодні IT-сектор, який тяжіє до реального сектору економіки, уже забезпечує формування близько $4 \%$ ВВП, створивши робочі місця щонайменше ста п'ятдесяти тисячам українцям. Креативна індустрія як така не в змозі замінити інші галузі виробництва, які є основою життєдіяльності суспільства, але стає їхньою креативною складовою та каталізатором розвитку [1].

Держава повинна підтримувати високотехнологічні наукоємні галузі, які потребують інноваційних ідей, оригінальних підходів та креативних рішень в їхньому розвитку.

Впровадження креативних індустрій у базові галузі економіки, зростання їхньої креативної складової обіцяє більший приріст ВВП порівняно з власне креативними індустріями. 
ТЕОРЕТИЧНІ ПРОБЛЕМИ РОЗВИТКУ НАЦІОНАЛЬНОЇ ЕКОНОМІКИ

У складі державних пріоритетів має бути підтримка інноваційних виробництв, що мають розробки світового рівня, щодо створення відповідних брендів для підвищення їх конкурентоспроможності на вітчизняному й міжнародному рівнях. Держава повинна інвестувати розробку нових технологій і креативних індустрій, що спрямовані на базові галузі економіки, які мають перспективи свого розвитку.

Поширення креативних індустрій формує креативну економіку. Концепція креативної економіки сформувалась на початку 2000 -х років і грунтується на тому, що індустріальну економіку замінює економіка нових ідей, тобто творчості. Креативна економіка формує вищі технологічні уклади, що є засобом підвищення конкурентоспроможності України у світовому економічному просторі [5].

Рушійною силою креативної економіки в реальному секторі є вчені, дослідники, інженери, конструктори, технологи та інші представники інтелектуальної еліти інноваційно-активних підприємств.

У XXI столітті креативна економіка буде визначати пріоритети розвитку, формувати зайнятість і стане стимулом та засобом створення нових стандартів якості життя з використанням потенціалу креативних індустрій.

Термін «креативні індустрії» вперше був введений у наукове коло в 90-х роках XX ст. у Великобританії, коли в 1997 році уряд намагався визначити та оцінити прямий вплив креативних індустрій на англійську економіку та створив Департамент 3 питань культури, ЗМІ і спорту, які міжгалузеву команду творчих індустрій (Creative Industries Task Force) і означав: «набір тих галузей промисловості, які мають своє походження в індивідуальній творчості, майстерності і таланті, і які мають потенціал для створення добробуту, робочих місць шляхом виробництва і використання інтелектуальної власності» [1; 7].

Водночас згідно з підсумками конференції ОOH з торгівлі та розвитку UNCTAD (United Nations Conference on Trade and Development) було визначено креативний сектор як «процеси створення, виробництва та розподілу товарів і послуг, де основою виступає креативність і інтелектуальний капітал. Вони складають комплекс заходів, в яких підгрунтям слугують знаннях, потенційно зосереджений, але не обмежується мистецтвом отримання доходів від торгівлі та прав інтелектуальної власності. Вони включають в себе матеріальні та нематеріальні товари, креативні художні послуги, економічна цінність та маркетингові цілі» [9].

Креативні індустрії в реальному секторі економіки виявляються в інноваціях і спрямовані в багатьох випадках на створення нових ідей та інтелектуальної власності в науково-інноваційній, техніко-технологічній, організаційно-економічній сферах, які забезпечують матеріальну основу життєдіяльності суспільства та кожної людини окремо. Накопичення креативних індустрій сприяе трансформації індустріального суспільства в постіндустріальне, яке характеризується розвитком науки, технологій, економіки знань (рис. 1).

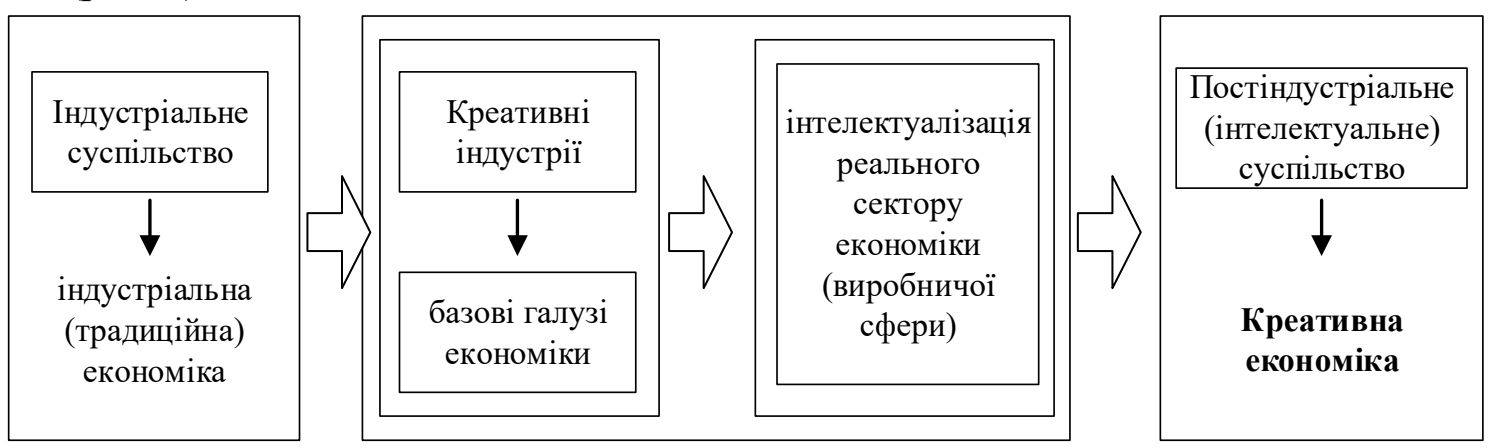

Рис. 1. Умови формування креативної економіки

Джерело: складено авторами. 
ТЕОРЕТИЧНІ ПРОБЛЕМИ РОЗВИТКУ НАЦІОНАЛЬНОЇ ЕКОНОМІКИ

Актуалізація розвитку креативних індустрій i, відповідно, креативної економіки здійснюється за умов, коли індустріальна в повному обсязі виконує свої функції щодо задоволення перших ступенів ієрархії потреб за А. Маслоу. Якщо суспільство загалом і окрема людина зокрема не задоволені базовими життєвими потребами, які є необхідними для виживання: фізіологічні потреби (продукти харчування, напої і т. ін.); потреба в захисті (безпека життя, захист від фізичних і психологічних перевантажень та інших викликів і загроз) певні креативні індустрії (образотворче мистецтво, кінематограф, телебачення і радіо, музика та інші ії складові) відходять із пріоритетів іії інтересів. Креативна індустрія розквітає там, де існує високий життєвий рівень населення, де високі стандарти якості життя.

Проте на сьогодні креативні індустрії не обмежуються визначеними напрямами і сферами суспільної діяльності, за якими традиційно закріпилось визначення їх як креативних.

У своїй книзі «Креативна економіка» американський учений економіст Джон Хокінс на перші місця виділяе такі напрями креативних індустрій, як НДДКР та програмне забезпечення, винахідництво та інформаційні технології, що багато в чому стосується не тільки мистецтва, культури, телебачення і радіо, реклами, моди і т. ін., а й реального сектору економіки [6].

Креативні індустрії створюють інтелектуальну власність у вигляді патентів, авторських прав на промислові зразки, товарні марки, стосуються оригінальних розробок у різних галузях матеріального виробництва, що притаманно техніко-технологічній та науково-інноваційній сферам діяльності.

Креативна економіка не повинна розглядатися як особливий сектор економіки у сфері мистецтва, культури і т. ін., а і в інших сферах, зокрема техніко-технологічній, де креативні індустрії так само грунтуються на інтелектуальній цінності й ціннісних пріоритетах затребуваних ринком.

На сьогодні креативна економіка, що є результатом впровадження та поширення креативних індустрій в базових галузях, і яка грунтується на інтелектуальній праці, що приносить дохід від реалізації кінцевого інноваційного продукту, від передачі прав на інтелектуальну власність (патенти, промислові зразки й моделі, товарні марки тощо) стосується також і реального сектору економіки (рис. 2).

Традиційне розуміння креативних індустрій має бути розширеним у бік технікотехнологічної сфери економіки з акцентом на застосування інформаційних технологій, як базового елемента для підвищення конкурентоспроможності країни та матеріального виробництва, що більш актуально для постсоціалістичних країн [10].

Для країн, що розвиваються, креативні індустрії, які в нашому розумінні мають більш широке тлумачення, мають бути спрямовані не тільки у сферу мистецтва, культури кінематографу і т. ін., а головним чином у техніко-технологічну сферу, у розробку нової техніки й технологій для подолання технологічного відставання від розвинених країн світу, для вирішення соціально-економічних проблем розвитку суспільства.

Рівень технологічного та соціально-економічного розвитку країн визначає пріоритетність тих креативних індустрій, які, з одного боку, стають затребувані суспільством, а 3 іншого - дозволяють вирішити проблеми, які є нагальними для суспільства.

Необхідно спрямовувати зусилля на ті напрями економічної діяльності креативних індустрій, які забезпечують подолання кризових явищ у відповідних секторах економіки.

Креативна індустрія забезпечує творчий підхід до вирішення завдань не тільки у сферах мистецтва, культури та ін., а і в техніко-технологічній сфері, що є важливим фактором підвищення конкурентоспроможності реального сектору національної економіки. 


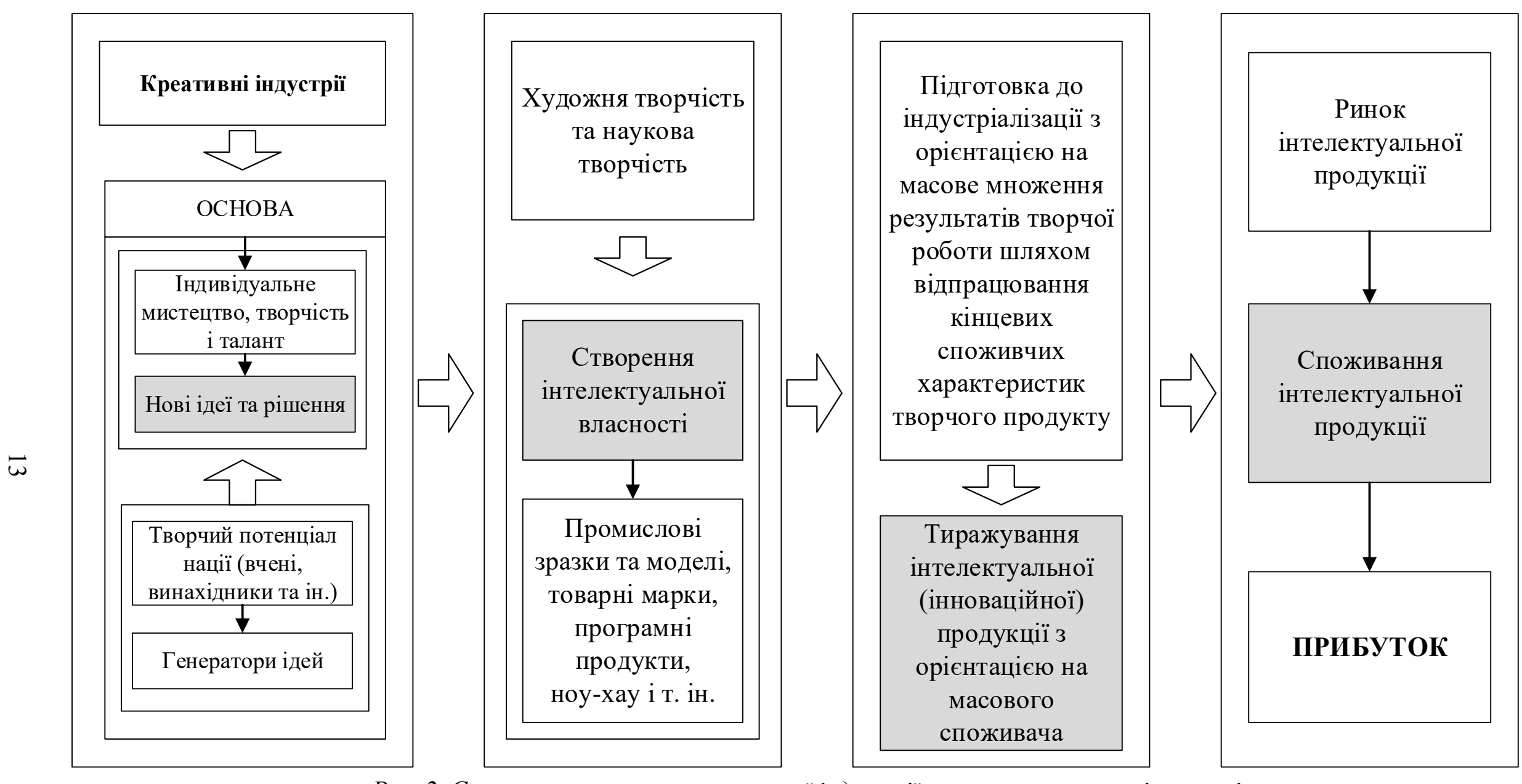

Рис. 2. Схема використання креативної індустрї в реальному секторі економіки

Джерело: складено авторами. 
ТЕОРЕТИЧНІ ПРОБЛЕМИ РОЗВИТКУ НАЦІОНАЛЬНОЇ ЕКОНОМІКИ

Креативна індустрія має бути спрямована на технологічний прорив національної економіки, на підвищення темпів науково-технологічного й соціально-економічного розвитку країни. Україна має всі передумови розвитку креативних індустрій, тому що наша країна посідає провідні позиції в розвитку інформаційних технологій, програмного забезпечення та комп'ютерних послуг. Розвиток креативних індустрій сприяє розвитку економіки, що забезпечується активізацією малого та середнього бізнесу, особливо у сфері технологічного підприємництва.

На сьогодні інноваційність вітчизняних промислових підприємств $є$ дуже низькою 3 негативною динамікою зниження кількості інноваційно-активних підприємств (рис. 3).

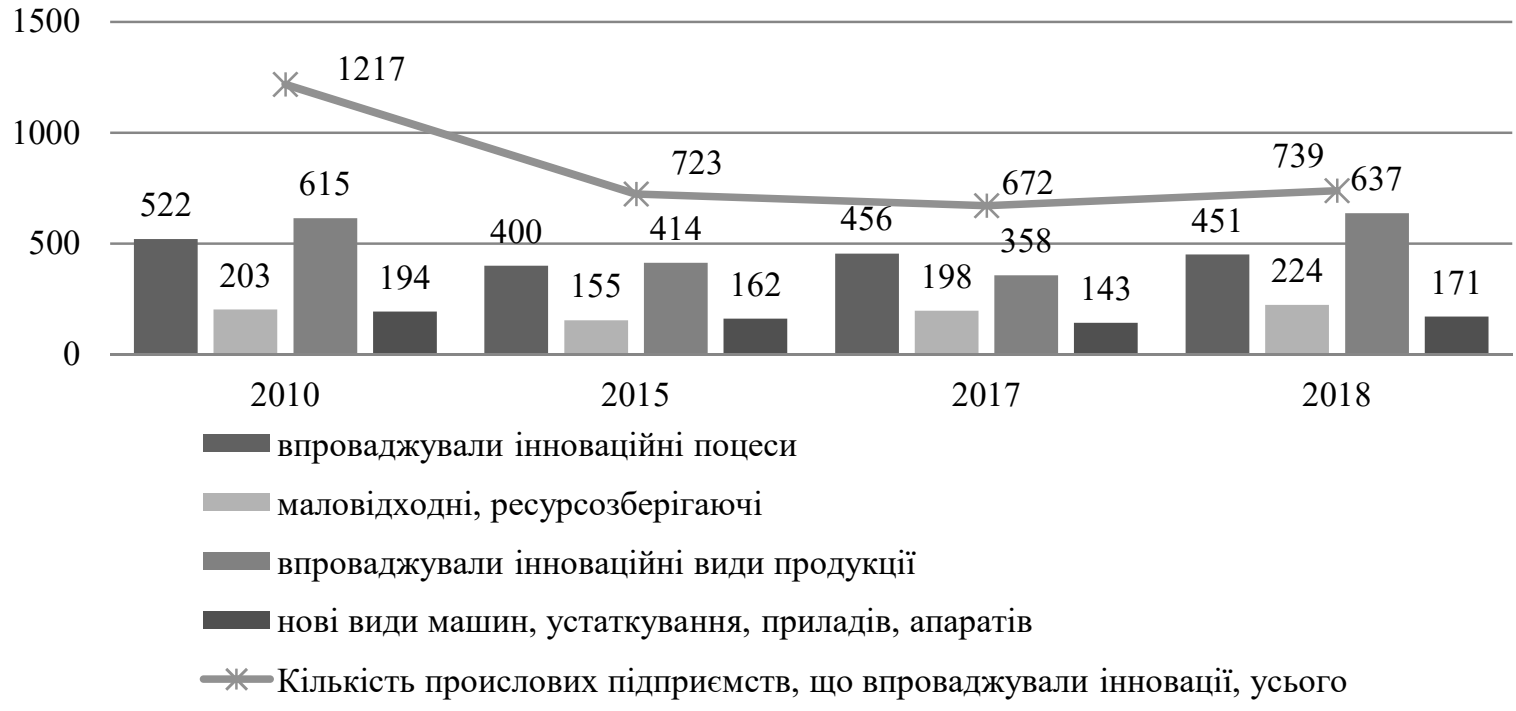

Рис. 3. Кількість промислових підприємств, щฺо впроваджували інноваџії, од. Джерело: складено авторами з використанням [4].

Що стосується створення технологічних інновацій за останні роки, то їхня структура за розміром підприємств показана на рис. 4.

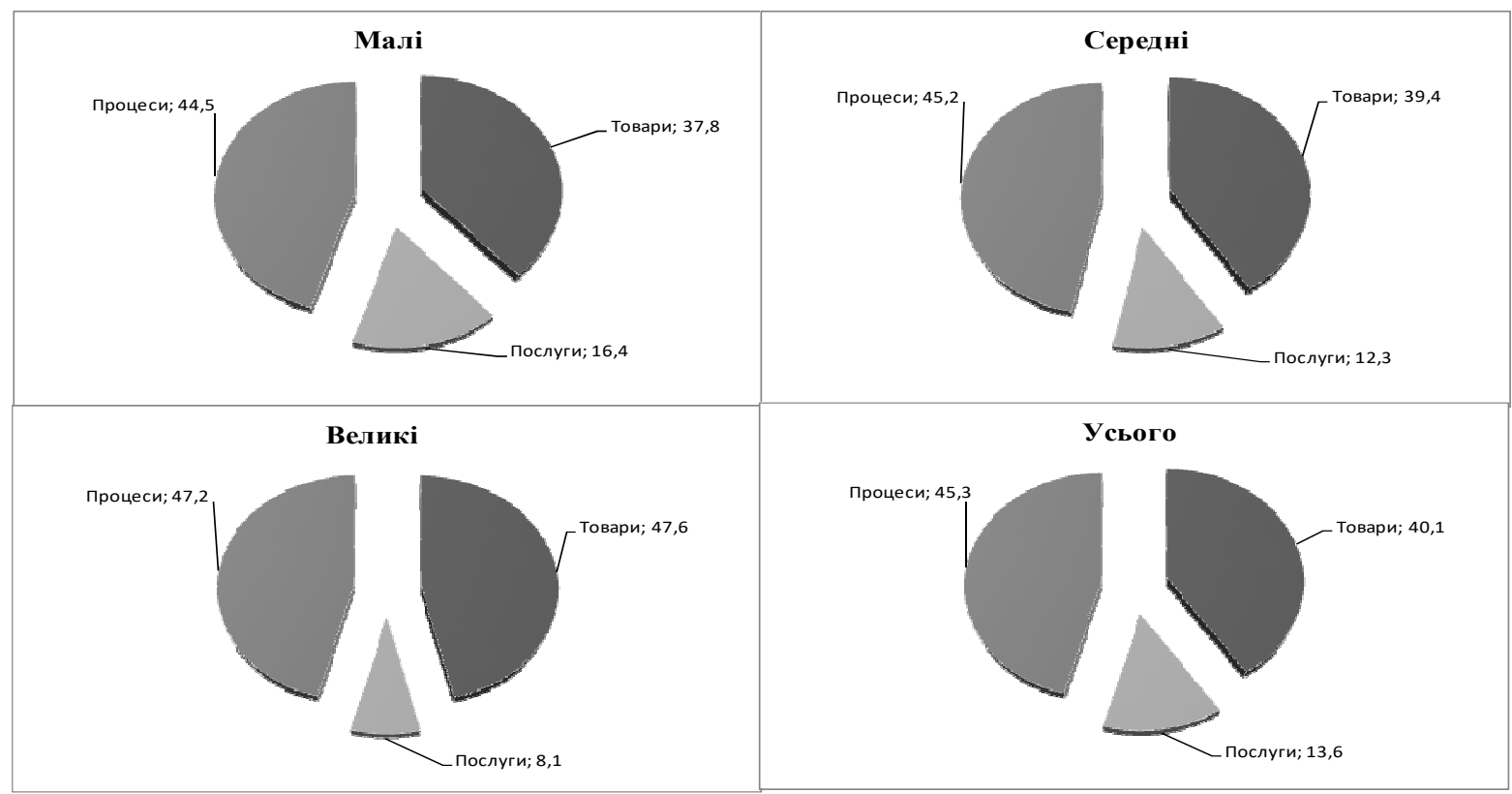

Рис. 4. Розподіл підприємств з технологічними інновачіями, які їх самостійно розробляли, за 2018 рік за типами інновачій та розміром підприємств, \% до загальної кількості підприємств із технологічними інноваціями

Джерело: складено авторами з використанням [4]. 
ТЕОРЕТИЧНІ ПРОБЛЕМИ РОЗВИТКУ НАЦІОНАЛЬНОЇ ЕКОНОМІКИ

Із рис. 4 видно, що загалом на всіх підприємствах у складі технологічних інновацій переважають процеси, які становлять близько $46 \%$, решту - товарні інновації, що певним чином актуалізують проблему розробки та впровадження креативних індустрій ринкового спрямування, тобто пов'язаних із комерціалізацією інноваційних рішень, спрямованих на створення нових товарів та послуг.

Поєднання виробництва і творчості (промисловий дизайн, промислові зразки та моделі й т. ін.) стають рушієм економічного зростання, ефективним засобом розвитку інноваційної економіки.

Креативна індустрія, потенціал якої весь час нарощується, є резервом і стимулом розвитку національної економіки, зокрема реального сектору.

Продукція креативної індустрії в усіх її проявах, зокрема й у науково-інноваційних, техніко-технологічній та виробничій сферах стає дедалі більш затребуваною на внутрішньому й зовнішньому ринках і створює позитивний імідж країни, що підвищує іiі конкурентоспроможність у світовому економічному просторі.

Креативні індустрії як вагомий сегмент економіки можна поділити на дві складові за напрямами їх прояву в економічному просторі країни.

Перша складова, в межах якої створюються переважно духовні блага, це власне креативні індустрії за їх традиційним розумінням, які реалізуються в таких видах економічної діяльності, як мистецтво і дизайн, музика, виконавче мистецтво, пам'ятники культури й туризм, художня творчість, відео та інтерактивна відеогра, мода та дизайн одягу, засоби масової інформації, кіно, вебдизайн, штучний інтелект, типографія, реклама, архітектура, традиційні ремесла, створення програмного забезпечення і т. ін.

Друга складова стосується виробничої сфери реального сектору економіки, де створюється матеріальна база добробуту та життєдіяльності суспільства. У межах другої складової проводяться НДДКР, здійснюється промислове винахідництво, розробка нових конструктивних рішень, машин, обладнання та устаткування, нових товарів і послуг, створюються безвідходні, ресурсозберігаючі, екологічно безпечні виробництва. Креативні індустрії, які притаманні реальному сектору економіки, реалізуються також у вигляді інформаційних технологій, програмного забезпечення, промислового дизайну, формування бренду, маркетингу, інструментів просування продукції на споживчий ринок і т. ін. Зазначені складові креативних індустрій мають спільні напрями економічної діяльності, які забезпечують вирішення притаманних для них завдань як у сфері створення духовних, так і матеріальних благ (рис. 5).

Поширення креативних індустрій сприяє формуванню креативної економіки, яка на сьогодні визнана складовою традиційної економіки і яка демонструє тенденцію свого зростання. Креативні індустрії сприяють динамічному розвитку найбільш прогресивних секторів національної економіки, які формують найвищі технологічні уклади.

Розвиток креативних індустрій для національної економіки - це шлях до інноваційного прориву в базових галузях виробництва, підвищення їх конкурентоспроможності у світовому економічному просторі.

Креативна індустрія та креативна економіка менше прив'язана до матеріальних ресурсів і спрямована на створення і реалізацію високих ресурсозберігаючих технологій за рахунок створення інноваційної техніки і технологій, що можливо завдяки використанню нових методів, інструментів та механізмів, які надає креативна економіка.

Креативна індустрія забезпечує творчий підхід до вирішення завдань і стає важливим фактором підвищення конкурентоспроможності всіх секторів національної економіки. Потенціал креативних індустрій здатний активізувати ті напрями економічної діяльності, які перебувають у кризі. 


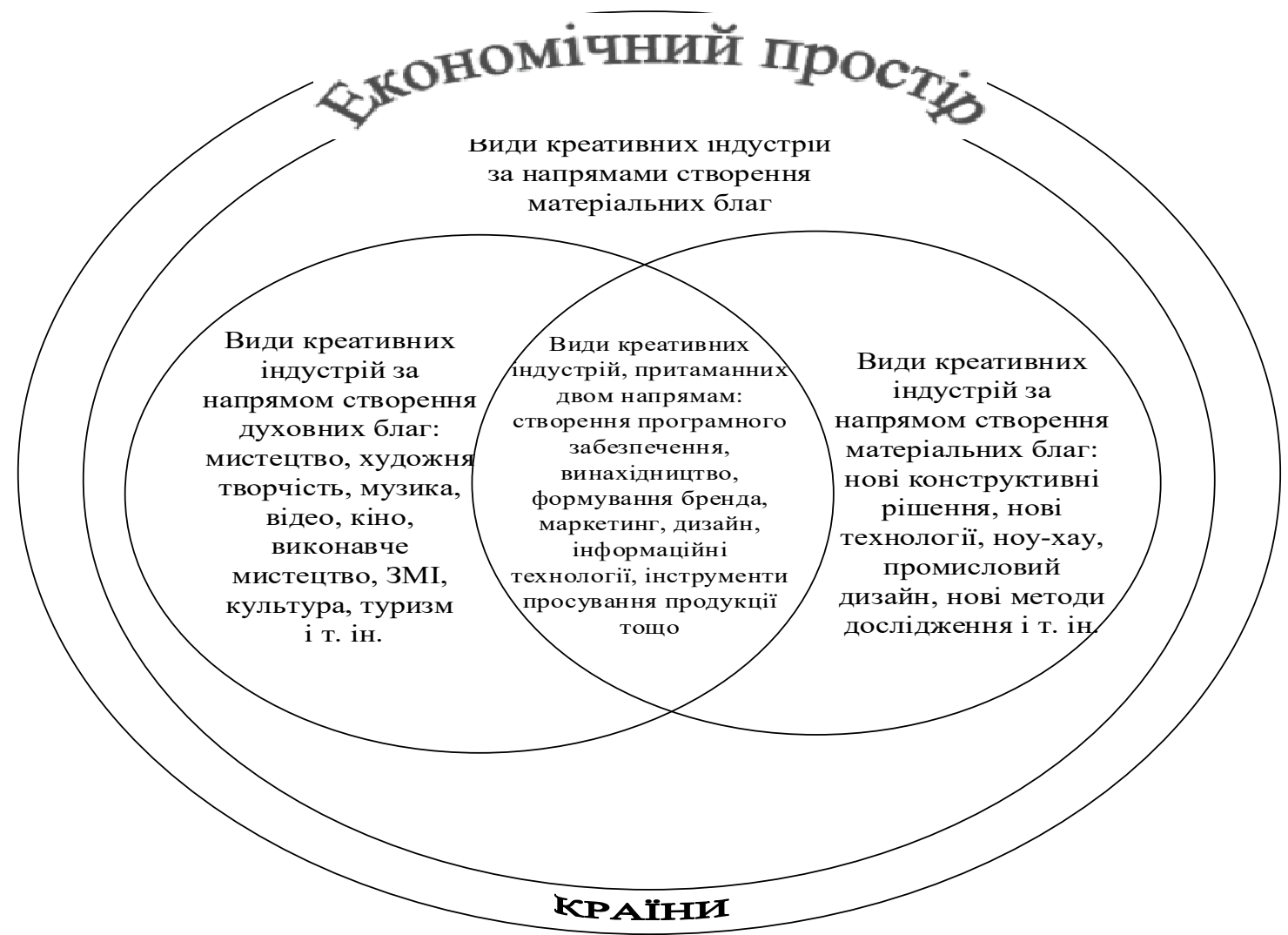

Рис. 5. Види креативних індустрій за напрямами створення духовних та матеріальних благ

Джерело: складено авторами.

Креативні індустрії в процесі формування креативної економіки мають охоплювати всі сфери, які мають комерційну спрямованість або вже комерціалізувались у процесі поглиблення ринкових відносин. Вплив креативних індустрій на розвиток креативної економіки (рис. 6) показує їх всеосяжну дію на всі сфери функціонування суспільства.

Креативні індустрії виявляються у вигляді інновацій, тісно з ними пов'язані за методами генерації нових ідей та комерціалізації вдалих рішень, знахідок та пропозицій. Потенціал креативних індустрій базується на можливостях, здібностях та таланті людей, здатних мислити неординарно. Інтелектуальні здібності, творча здатність до генерування нових ідей $є$ головним ресурсом креативної індустрії.

Креативність має запроваджуватись у всіх сферах економічної діяльності, оскільки творчий підхід забезпечує конкурентоспроможність будь-якого бізнесу. Творчий підхід стає гарантом успіху й основою економіки.

3 огляду на те, що сучасний ринок $є$ досить мінливим та динамічним із невизначеними тенденціями розвитку, коли споживацькі очікування постійно зростають, використання креативних індустрій дозволяє знайти оптимальні рішення у сфері науковотехнічних розробок, щоб забезпечити конкурентоспроможність підприємства в умовах непередбачуваної зміни кон'юнктури ринку.

Гнучкий підхід до вирішення нагальних питань у сферах генерації оригінальних ідей, створення інноваційного продукту, просування його на ринок і т. ін. неможливий без творчості. Творчість певною мірою можна вважати продуктивним ресурсом, який дозволяє вирішити багато питань у різних сферах діяльності суб'єктів господарювання. Нині інноваційність продукції забезпечує іiі конкурентоспроможність на внутрішньому й зовнішньому ринках, створює позитивний імідж для виробника, підвищує його інвестиційну привабливість та перспективу сталого економічного зростання. 


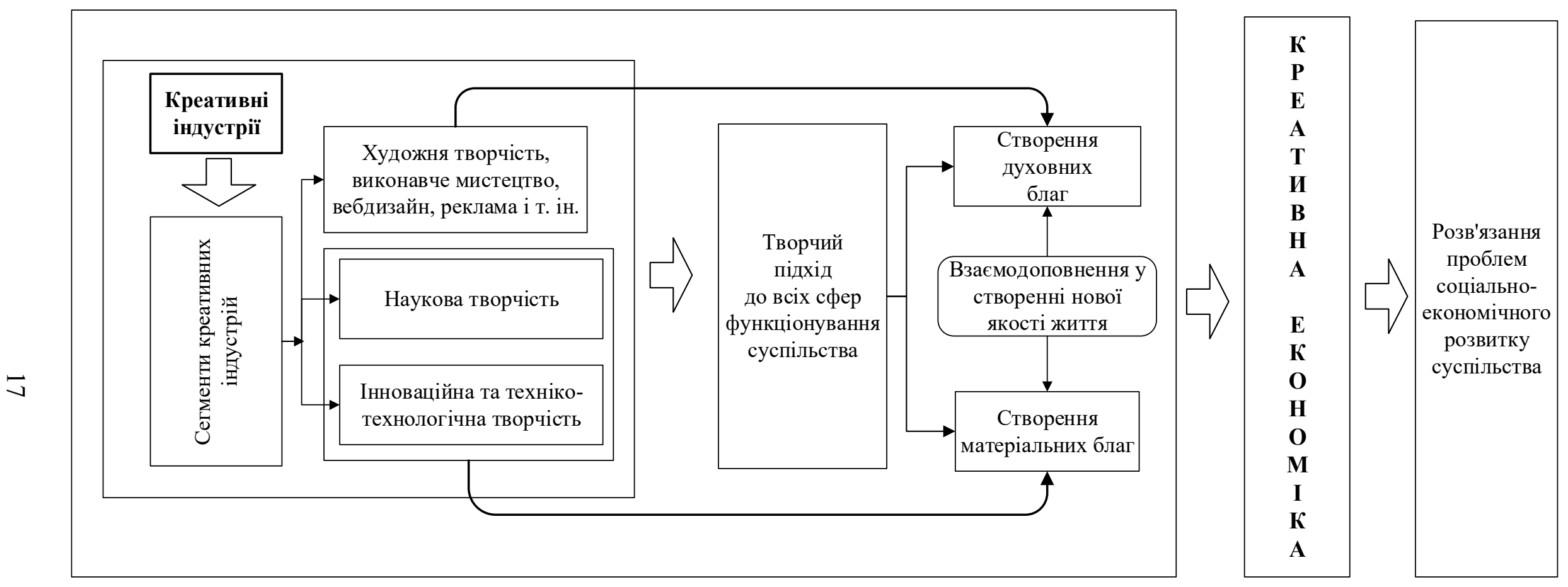

Рис. 6. Вплив креативних індустрій на розвиток креативної економіки

Джерело: складено авторами. 
ТЕОРЕТИЧНІ ПРОБЛЕМИ РОЗВИТКУ НАЦІОНАЛЬНОЇ ЕКОНОМІКИ

Наявність творчого потенціалу підприємства багато в чому перевершує інші його можливості й ресурси, що пояснюється необмеженими можливостями креативного мислення генерувати продуктивні ідеї, які здатні вирішити будь-які проблеми виробничого, науково-технологічного чи організаційно-економічного характеру.

Неординарність мислення та креативний підхід до вирішення нагальних проблем розвитку техніки та технологій може забезпечити успіх і випередити час.

В історії є приклади генерації нових ідей, що виникли на межі можливого і на перший погляд неприйнятного з погляду існуючих традиційних поглядів і розуміння явищ і процесів.

Йдеться про створення турбореактивного двигуна, конструктивні рішення якого запропонував український учений, конструктор, спеціаліст у галузі авіаційних двигунів Архип Михайлович Люлька [2].

На перший погляд неможливо було конструктивно й технологічно поєднати в одному агрегаті два принципово різні фізичні процеси, які стосуються реактивної тяги i турбіни. Проте більш глибокий аналіз запропонованої «безглуздої» на перший погляд ідеї та випробування дослідного зразка показали можливість створення надійного турбореактивного двигуна, який широко використовуються в авіації.

Це ще раз підтверджує вислів, що творчість стає важливим стимулом інновацій, нових конструкторських рішень та засобом удосконалення виробництва.

Висновки та пропозиції. Отже, можна стверджувати, що креативна економіка на сьогодні $є$ ключовою складовою стратегії розвитку суспільства, основою якого є безперервний інноваційний та творчий розвиток, який грунтується на інтелектуальному капіталі. Креативність мислення є запорукою генерації нових ідей, накопичення нових знань, нових оригінальних рішень, створення нової якості традиційних товарів і послуг.

Креативні індустрії в реальному секторі національної економіки є вагомим засобом підвищення технологічного рівня вітчизняного виробництва та забезпечення Україні статусу розвиненої високотехнологічної держави.

\section{Список використаних джерел}

1. Кукса I. М., Пехухова Т. О. Креативна економіка як інноваційної та стійкої стратегії розвитку України. Ефективна економіка. 2017. № 12. URL: http://www.economy.nayka.com.ua/?op=1\&z=6555.

2. Люлька Архип - авіаконструктор. URL: https://kolokray.com/uk/f/lyulka-arhipaviakonstruktor.html.

3. Навчальний економічний словник-довідник (політекономія, мікроекономіка, макроекономіка, економічний аналіз, економіка підприємства, менеджмент, маркетинг, фінанси, банки, інвестиції, біржова діяльність, планування): Терміни, поняття, персоналії / уклад.: В. С. Іфтемічук та ін. ; за наук. ред. Г. І. Башнянина і В. С. Іфтемічука. 2-ге видання, виправлене і доповнене. Львів : Магнолія 2006, 2008. 688 с.

4. Наука та інноваційна діяльність України : статистичний збірник / Державний служба статистики України, Київ, 2018. 178 с.

5. Отечественный IT-сектор обеспечивает 4 \% ВBП Украины. URL: https://www.unian.net/ economics/finance/10444737-otechestvennyy-it-sektor-obespechivaet-4-vvp-ukrainy.html.

6. Хокинс Дж. Креативнас экономика. Москва : Издательский дом «Классика-XXI», 2011. 256 c. URL: http://vkist.ru/djon-hokins-kreativnaya-ekonomika/50423.pdf.

7. Шкарлет С. М., Дубина М. В. Особливості взаємодії креативних індустрій та фінансових установ. Проблеми перспективи економіки та управління. 2019. № 1 (17). С. 207-218.

8. Creative Industries Mapping Document 1998. URL: https://www.gov.uk/government/ publications/creative-industries-mapping-documents-1998.

9. UNCTAD, Creative Economy Outlook and Country Profiles: Trends in international trade in creative industries, 2015. URL: http://unctad.org/en/PublicationsLibrary/webditcted2016d5_en.pdf. 
ТЕОРЕТИЧНІ ПРОБЛЕМИ РОЗВИТКУ НАЦІОНАЛЬНОЇ ЕКОНОМІКИ

10. Vdovenko N., Deriy J., Seliverstova L., Kurmaiev P. Formation of the information economy: Organizational and financial aspects. International Journal of Supply Chain Management. 2019. Vol. 8. № 4. P. 956-961.

\section{References}

1. Kuksa, I. M., Pyetukhova, T. O. (2017). Kreatyvna ekonomika yak innovatsiynoyi ta stiykoyi stratehiyi rozvytku Ukrayiny [Creative Economy as an Innovative and Sustainable Development Strategy of Ukraine]. Efektyvna ekonomika - Effective Economics, 12. Retrieved from $\mathrm{http} / / / \mathrm{www} \cdot$ economy.nayka.com.ua/?op=1\&z=6555.

2. Liulka Arkhyp - aviakonstruktor [Lyulka Arkhip is an aircraft designer]. Retrieved from https://kolokray.com/uk/f/lyulka-arhip-aviakonstruktor.html.

3. Iftemichuk, V. S., Hryhoriev, V. A., Manilych, M. I., Shutak, H. D. (2008). Navchalnyi ekonomichnyi slovnyk-dovidnyk (politekonomiya, mikroekonomika, makroekonomika, ekonomichnyy analiz, ekonomika pidpryyemstva, menedzhment, marketynh, finansy, banky, investytsiyi, birzhova diyal'nist', planuvannya): Terminy, poniattia, personalii [Educational economic dictionary-directory (political economy, microeconomics, macroeconomics, economic analysis, enterprise economics, management, marketing, finance, banks, investments, stock exchange activities, planning): Terms, concepts, personnel]. Lviv: Magnolia [in Ukraine].

4. Nauka ta innovatsiina diialnist Ukrainy: statystychnyi zbirnyk [Science and innovation activity of Ukraine. Statistical collection] (2018). Kyiv: Derzhavna sluzhba statystyky Ukrainy [in Ukraine].

5. Otechestvennyi IT-sektor obespechivaet $4 \%$ VVP Ukrainy [The domestic IT sector provides 4\% of Ukraine's GDP]. Retrieved from https://www.unian.net/economics/finance/10444737otechestvennyy-it-sektor-obespechivaet-4-vvp-ukrainy.html.

6. Khokins, Dzh. (2011). Kreativnaya ekonomika [Creative economy]. Retrieved from http://vkist.ru/djon-hokins-kreativnaya-ekonomika/50423.pdf.

7. Shkarlet, S. M., Dubyna, M. V. (2019). Osoblyvosti vzaiemodii kreatyvnykh industrii ta finansovykh ustanov [Features of interaction creative industries and financial institutions]. Problemy perspektyvy ekonomiky ta upravlinnia - Problems and prospects of economics and management, 1 (17), 207-218 [in Ukrainian].

8. Creative Industries Mapping Document (1998). Retrieved from https://www.gov.uk/government/ publications/creative-industries-mapping-documents-1998.

9. UNCTAD (2015) Creative Economy Outlook and Country Profiles: Trends in international trade in creative industries. Retrieved from http://unctad.org/en/PublicationsLibrary/ webditcted2016d5 en.pdf.

10. Vdovenko, N., Deriy, J., Seliverstova, L., Kurmaiev, P. (2019). Formation of the information economy: Organizational and financial aspects. International Journal of Supply Chain Management, 8 (4), 956-961.

|Ільчук Валерій Петрович - доктор економічних наук, професор кафедри фінансів, банківської справи та страхування, Чернігівський національний технологічний університет (вул. Шевченка, 95, м. Чернігів, 14035, Україна).

Ильчук Валерий Петрович - доктор экономических наук, профессор кафедры финансов, банковского дела и страхования, Черниговский национальный технологический университет (ул. Шевченко, 95, г. Чернигов, 14035, Украина).

Ilchuk Valerii - Doctor of Economics. Professor of Finance, Banking and Insurance, Chernihiv National University of Technology (95 Shevchenka Str., 14035 Chernihiv, Ukraine).

E-mail: ivp5@ukr.net

ORCID: http://orcid.org/0000-0003-4844-1326

Садчикова Ірина Володимирівна - кандидат економічних наук, доцент кафедри фінансово-економічної безпеки Чернігівський національний технологічний університет (вул. Шевченка, 95, м. Чернігів, 14035, Україна).

Садчикова Ирина Владимировна - кандидат экономических наук, доцент кафедры финансовоэкономической безопасности, Черниговский национальный технологический университет (ул. Шевченко, 95, г. Чернигов, 14035, Украина).

Sadchykova Iryna - PhD in Economics, Associate Professor of Financial and Economic Security Department,

Chernihiv National University of Technology (95 Shevchenka Str., 14035 Chernihiv, Ukraine).

E-mail: aspirant_chstu@ukr.net

ORCID: https://orcid.org/0000-0001-5144-1306

Researcher ID: F-4936-2014

Ільчук В., Садчикова I. Теоретичні засади формування креативних індустрій у розвитку реального сектору національної економіки. Проблеми і перспективи економіки та управління. 2020. № 1 (21). С. 9-19. 